\title{
Board Attributes, Corporate Social Responsibility Strategy, and Corporate Environmental and Social Performance
}

\author{
Forthcoming in the Journal of Business Ethics
}

(DOI: 10.1007/s10551-014-2460-9)

\author{
Amama Shaukat $\dagger$ \\ (A.Shaukat@ex.ac.uk) \\ University of Exeter Business School
}

\author{
Yan Qiu \\ (Yan.Qiu@mbs.ac.uk)
}

Manchester Business School

\author{
Grzegorz Trojanowski \\ (G.Trojanowski@ex.ac.uk) \\ University of Exeter Business School
}

\begin{abstract}
In this paper we draw on insights from theories in the management and corporate governance literature to develop a theoretical model that makes explicit the links between a firm's corporate social responsibility (CSR) related board attributes, its board CSR strategy, and its environmental and social performance. We then test the model using structural equation modeling approach.

We find that the greater the CSR orientation of the board (as measured by the board's independence, gender diversity, and financial expertise on audit committee), the more proactive and comprehensive the firm's CSR strategy, and the higher its environmental and social performance. Moreover, we find this link to be endogenous and self-reinforcing, with superior CSR performers tending to further strengthen their board CSR orientation. This result while positive is also suggestive of the widening of the gap between the leads and laggards in CSR. Therefore the question arises as to how 'leaders' are using their superior CSR competencies seen by many scholars as a source of corporate (at times unfair) competitive advantage. Stakeholders of corporations therefore need to be cognizant of this aspect of CSR when evaluating a firm's CSR activities. Policy makers also need to be cognizant of these concerns when designing regulation in this field.
\end{abstract}

Keywords: Board of directors, Corporate governance, Corporate Social Responsibility (CSR), Resource-based view (RBV), Resource dependence theory (RDT), Structural equation modeling (SEM)

\footnotetext{
$\dagger$ Corresponding author. Address for correspondence: University of Exeter Business School, Streatham Court, Rennes Drive, Exeter EX4 4PU, UK. Tel: +44 1392 722585, fax: +44 1392722575.
} 


\section{Introduction}

Research in the field of corporate environmental and social responsibility generally referred to as corporate social responsibility (CSR) has attracted the attention of scholars from diverse disciplines including management and corporate governance. Drawing from the management literature, particularly the resource-based view of the firm (RBV) theory, scholars have argued that firms possessing unique human resources like superior managerial capabilities, as well as superior organizational strategies such as proactive environmental strategies, are able to develop competitive advantages in CSR, which in turn enable such firms to achieve superior environmental and economic performance (Al-Tuwaijri et al. 2004; Clarkson et al. 2011; Hart 1995; Porter and van der Linde 1995; Russo and Fouts 1997). A significant limitation of this literature is that while managerial capability and superior environmental strategies are assumed to be the main factors driving superior environmental performance, these variables are neither directly measured, nor explicitly incorporated in the research design leading to conceptually incomplete analysis (e.g. Al-Tuwaijri et al. 2004; Clarkson et al. 2011; Russo and Fouts 1997). This paper conceptually and methodologically advances this stream of literature by explicitly measuring and incorporating in the research design variables that measure a firm's board level CSR orientation and its board CSR strategy, linking these with the firm's environmental and social performance. Our analysis thus helps advance the RBV-based CSR literature, explicitly identifying the board level human resources and strategies that can help firms achieve a competitive edge in the field of CSR, often seen as the new battleground for corporate competitive advantage (Galbreath 2010; Hart 1995; Lash and Wellington 2007; Porter and Reinhardt 2007).

In recent years, scholars working in the field of corporate governance have also started taking a keen interest in the study of CSR. This is in line with the broadening scope of corporate governance (CG) which is no longer seen to be limited to aligning the interest of 
the managers of public corporations with those of its capital providers (as per agency theory, Jensen and Meckling 1976), but also of the firm with those of its wider stakeholders (Aguilera et al. 2007; (UK) Companies Act 2006; Jensen 2002; Rodrigue et al. 2013; UK Code of Corporate Governance 2010). Within this literature the role of the board, which is the apex decision making body in a public corporation, has been the main focus of attention. Accordingly, scholars drawing upon the agency or the resource dependence theory (RDT, Boyd 1990; Hillman et al. 2000; Hillman and Dalziel 2003; Pfeffer 1972, 1973; Pfeffer and Salancik 1978) examine the link between various board attributes, including outside/independent director attributes and measures of corporate social performance (e.g. Johnson and Greening 1999; Jo and Harjoto 2011, 2012; Mallin and Michelon 2011; Post et al. 2011; Webb 2004). These studies argue that certain directors, particularly outside directors, serve on a board to provide effective managerial oversight (as per agency theory, Fama and Jensen 1983), as well as to play an effective resource dependence role (Pfeffer and Salancik 1978) by providing essential resources to a firm or by helping the firm secure these resources through linkages with its external environment (cf. Pfeffer 1973; Hillman et al. 2000). There are two significant limitations of this literature. First, most of it considers board director attributes to be exogenous (e.g. Mallin and Michelon 2011; Rodrigue et al. 2013). Second, it is conceptually incomplete in the sense that it does not clearly identify board actions/decisions that contribute to superior CSR performance. However, it is widely acknowledged within the corporate governance literature (e.g. Adams et al. 2010; Agrawal and Knoeber 1996; Hermalin and Weisbach 1998, 2003) that board of director characteristics and firm performance are endogenous outcomes. Moreover it is also proposed by Hermalin and Weisbach (2003) that this link is mediated by board actions/decisions, which research to date has largely assumed away - a significant caveat in governance-performance type research highlighted in recent literature reviews (cf. Adams et al. 2010; Johnson et al. 2013). 
Our study thus contributes to the corporate governance-related CSR literature both conceptually as well as methodologically, by developing and testing a theoretical model (adapted from Hermalin and Weisbach 2003) which makes explicit the potentially endogenous links between CSR-related director attributes, board CSR-related strategic decisions, and corporate environmental and social performance. In doing so, it also directly responds to the need for developing a better understanding of the decisions and activities that a board undertakes to address the growing corporate environmental and social challenges (Mallin et al. 2013).

The empirical analysis based on the proposed theoretical model, suggests that firms with more CSR oriented boards (i.e. those with more independent directors, women directors as well as directors possessing financial expertise sitting on the audit committee) develop a more proactive and comprehensive board CSR strategy (i.e. one which combines internal CSR strengths with external CSR reputation building measures). Such firms in turn achieve superior environmental and social performance. We also find this link to be endogenous and self-reinforcing, with firms having superior environmental and social performance, further strengthening their board level CSR orientation. Overall these results are in line with the predictions of RDT as well as RBV theory. Our findings shed light on the board level human resources and strategies required to achieve superior environmental and social performance. They also lend support to the key RBV theory prediction (Hart 1995; Russo and Fouts 1997) that in order to sustain competitive advantages in the field of CSR, proactive CSR oriented firms tend to keep building on their CSR strengths (as the positive cyclical link suggests).

Our paper also makes a more general contribution: the theoretical model and empirical approach developed in this paper can be applied to guide any future investigation of the link between board attributes, board decisions, and firm performance outcomes, be it in the field of CSR or corporate governance in general. 
The rest of the paper is organized as follows. The next section discusses the relevant literature and develops the theoretical model with its set of interconnected testable hypotheses. It is followed by the discussion of the variables and structural model specifications. Next we discuss the sample and the data, and, subsequently, analyze the results. Finally, we present the conclusions, implications, and limitations of this study.

\section{Literature Review, Theoretical Model, and Hypothesis Development}

As scholars and policy makers widen the remit of corporate governance to include corporate responsibilities towards not only the shareholders but also other stakeholders of the firm (e.g. Jensen 2002; Rodrigue et al. 2013; (UK) Companies Act 2006; UK Corporate Governance Code 2010), in recent years academic research has examined the link between various governance mechanisms, particularly the board related characteristics and a firm's CSR performance. These studies have drawn upon the agency and the resource dependence theory perspectives. From the agency theory perspective, the board of directors (particularly the outside directors on the board) is considered to be decision control experts with reputational concerns (Fama and Jensen 1983). Hence they have incentives to perform an effective monitoring task which includes protecting the interests of not just the shareholders but also other stakeholders of the firm (Johnson and Greening 1999). Applying such a logic, Johnson and Greening (1999) argue that non-executives on a board are likely to have a wider stakeholder perspective in strategic decision making as opposed to a narrow shareholder perspective often adopted by top management, concerned with meeting short term shareholder oriented performance targets. Consistent with these arguments, Johnson and Greening (1999) find a positive link between outside director representation on the board and measures of corporate social performance. More recently, Jo and Harjoto $(2011,2012)$ also find that effective corporate governance mechanisms including independent boards, promote 
CSR engagement, thus helping reduce the conflicts between the firm and its wider stakeholders, and positively influencing firm value.

The resource dependence theory (RDT) is the perspective recently drawn upon by scholars to explain the role of the board in achieving CSR objectives (e.g. Mallin and Michelon 2011; Mallin et al. 2013). The board is seen from the RDT perspective as a resource for managing a firm's external environmental dependencies and uncertainties, such as those posed by the social and natural environmental challenges (Pfeffer 1972, 1973; Pfeffer and Salancik 1978; Hillman et al. 2000). Based on a comprehensive review of prior relevant research, Hillman and Dalziel (2003) outline key resource dependence related contributions of the board, namely: enhancing the legitimacy and public image of the firm; providing expertise; providing advice and counsel; linking the firm to important stakeholders or other important entities; facilitating access to resources; building external relations; and aiding in the formulation of strategy and other important firm decisions. Therefore, these board contributions have a direct relevance for a firm's CSR. For instance, gaining social legitimacy and positive stakeholder reputation are considered vital for economic success in today's natural resource-depleted, stakeholder-sensitive business climate (Hart 1995; Hillman and Keim 2001; Jensen 2002, Porter and Kramer 2006). To this end, a firm has to have the right mix of directors, particularly outside directors who can bring the diversity of knowledge, skills, experience, expertise, and ties (Fama and Jensen 1983; Pfeffer and Salancik 1978); as well as a broader stakeholder orientation (Wang and Dewhirst 1992) that can help develop an effective CSR strategy leading to superior CSR performance. Consistent with such arguments, studies tend to find a positive association between the proportion of outside directors including women directors and various measures of CSR performance (Mallin and Michelon 2011; Post et al. 2011; Webb 2004). For example, Mallin and Michelon (2011) draw upon the RDT and argue that, as providers of both human and relational capital, outside directors and 
women directors can enhance a firm's social performance and its reputation by developing useful relationships with the firm's stakeholders. Such directors are also argued to provide insightful advice to top management about stakeholders' expectations. Consistent with these arguments, Mallin and Michelon (2011) find a positive link between a number of board attributes including board independence and gender diversity on the board. Similar results are also found by Post et al. (2011) who find that firms with higher proportion of outside directors and those with three or more female directors tend to have higher Kinder Lydenberg Domini (KLD) strengths scores. Webb (2004), who investigates the differences in the structure of the board of directors between socially responsible and matched non-responsible firms, also finds that socially responsible firms tend to have larger boards, more independent board members, and more women on their boards. Thus, prior studies tend to find a positive association between various board attributes, particularly board independence and gender diversity, and measures of corporate social performance.

It is important to note though that most prior studies examining the link between board characteristics and CSR performance tend to treat the board attributes as exogenous. However, it is widely acknowledged in the corporate governance literature (e.g. Adams et al. 2010; Agrawal and Knoeber 1996; Hermalin and Weisbach 1998, 2003) that the composition of the board of directors of a company is an endogenous outcome. Discussing the perils of ignoring the exogenous or endogenous interpretation of most governance research, Hermalin and Weisbach $(2003$, p. 8) note that " $[\mathrm{w}]$ hile it is generally difficult to distinguish between the two interpretations in a given study, they often have drastically different implications for policy." To illustrate this point Hermalin and Weisbach (2003) cite Hermalin and Weisbach's (1998) finding of poor firm performance leading to increase in board independence and, note that "[i]n a cross-section this effect is likely to make firms with independent directors look worse..." It is precisely for this reason that Hambrick (2007, p. 338), notes that controlling for 
endogeneity in research is "not a technical nicety but, instead is essential for gaining a grasp of the causal mechanisms that lie behind empirical associations."

In an effort to conceptually tease out the board attributes-firm performance link, Hermalin and Weisbach (2003) present a theoretical model that makes explicit the expected endogenous links between board characteristics, board actions/decisions, and firm performance, reasoning that the characteristics-performance link is mediated by board actions/decisions. Their model points to another gap in the board characteristics-performance research: studies on board attributes-performance link assume away the board decisions that contribute to superior performance. This caveat has been reiterated again by recent literature reviews on boards by Adams et al. (2010) and Johnson et al. (2013). In this study, we adapt Hermalin and Weisbach's (2003) model and make explicit the expected endogenous links between board attributes, board decisions/actions and firm CSR performance. Moreover the use of structural equation modeling (SEM) technique allows us to take into account the potential endogeneity of this link in our analysis (cf. Bollen 1989).

Scholars have also approached the study of CSR performance from a management perspective. Studies in this stream of literature tend to draw upon the resource-based view of the firm (RBV) and argue that it is the firm-specific unique resources including physical assets and financial resources, but more importantly unique human competencies and organizational strategies that create sustainable competitive advantages for firms. Among the first to apply this theory in the context of CSR was Hart (1995) who theorizes that proactive investments in environmental strategies, particularly those related to pollution prevention, product stewardship (i.e. manufacturing and promoting 'green' products) and sustainable (corporate) development could confer both environmental and economic benefits to firms. His analysis suggests that to be effective, CSR has to be adopted as a comprehensive strategy encompassing all aspects of a firm's operations rather than as odd bits and pieces of corporate 
social responsibility. Moreover, Hart (1995) also notes that for a sustained competitive advantage, internal competitive strengths need to be complemented by external social legitimacy. He thus highlights the importance of communicating these proactive environmental strategies to external stakeholders, which could "reinforce and differentiate a firm's position through the positive effects of a good reputation" (Hart 1995, p. 999). Russo and Fouts (1997) empirically test the predictions of RBV and find a positive link between environmental performance and firm operating profitability. They assume this link to be mediated by the unobserved superior environmental strategy, which they conjecture to be based on unique combinations of intangibles (such as human capital, reputation, and technology) and tangible assets (such as financial reserves and physical equipment). The RBV theory has also been applied by more recent CSR-related studies including those of AlTuwaijri et al. (2004) and Clarkson et al. (2011) who attribute their finding of a positive link between a firm's environmental and financial performance to the unobserved managerial quality and CSR strategy. Hence, while prior studies adopting RBV posit board human resource quality and superior environmental strategies to be responsible for superior environmental performance, they fail to explicitly incorporate any direct measures capturing CSR-conducive board human resources or CSR strategies. In this study, we conceptually and methodologically advance this stream of literature by explicitly modeling, measuring, and testing the link between board level CSR-conducive human resources, CSR strategy, and firm environmental and social performance. Figure 1 presents diagrammatically the omissions in the two streams of the extant CSR literature discussed above. It is worth noting that while under both theories the board would be regarded as a resource, under RBV the board would be regarded as a tacit (i.e. invisible), socially complex (i.e. based on team effort), and internal resource (Hart, 1995). Under RDT, it is considered as a visible link with the firm's external environment (Pfeffer and Salancik 1978). In other words, the board's roles in CSR under 
RBV and RDT can be considered complementary and is consonant with Hart's (1995, p. 998) key insight that "a purely internal (competitive) approach may prove inadequate because issues of external (social) legitimacy and reputation are also extremely important". Hence the board's CSR orientation is likely to be driven by both the firm's internal CSR-related needs, as well as its external CSR-related considerations.

\section{[Insert Figure 1 about here]}

While our discussion to this point makes clear the direction and nature of the causal positive links we expect between board CSR orientation, CSR strategy, and firm CSR performance, it does not clarify how CSR performance may affect board CSR orientation. There is an ongoing debate in the literature about the inter-relationships between corporate governance (CG) and corporate social responsibility (CSR). While most scholars agree that these are inter-related (see e.g. Aguilera et al. 2007; Jamali et al. 2008; Jensen 2002), the specific nature of the causal relation between the two has only recently been formally investigated. Specifically, Jo and Harjoto (2012) find that while desirable corporate governance mechanisms, including (lagged) board independence, affect CSR positively, no evidence of lagged CSR engagement affecting current corporate governance mechanisms (including board independence) is found. However, they do not posit any hypothesis as to why and in which direction the causality (if at all) could run from superior CSR engagement to pro-CSR governance mechanisms. Yet, there are theoretical grounds (discussed below) to suggest that a positive link may run from CSR performance to board CSR orientation.

Here we again draw upon the insights from RBV and RDT theories. Drawing on RBV theory, Hart (1995) maintains that for firms to sustain their competitive advantages in the field of environment, it is important to consistently build upon their internal human and organizational competencies and resources, as these may otherwise erode over time as 
competitors catch up. Russo and Fouts (1997) also stress the importance of nurturing and building resources through sustained actions for creating and maintaining a proenvironmental internal capabilities and external reputation. Consistent with these arguments, the composition of a board of directors is not only a unique internal resource, but also a source of building external linkages, reputation and social legitimacy - the view taken by the RDT theorists (Pfeffer 1972, 1973; Pfeffer and Salancik 1978). Hence, it can be argued that in order to build and nurture their CSR-conducive board resources as well as to build a positive stakeholder reputation (a valuable intangible resource and a source of corporate competitive advantage, Hart 1995), superior CSR performers may further strengthen their board level CSR orientation. Accordingly, we expect a positive link between CSR performance and board CSR orientation.

[Insert Figure 2 about here]

Figure 2 summarizes our theoretical model. Based on the preceding discussion and our theoretical model, we hypothesize the following inter-connected relations:

H1: The higher a board's CSR orientation, the more comprehensive the board level CSR strategy.

H2: The more comprehensive a firm's board level CSR strategy, the higher its environmental and social performance.

H3: The higher a firm's environmental and social performance, the higher its boardlevel CSR orientation. 


\title{
Variables and Models
}

\author{
Endogenous Variables
}

Board CSR Orientation. To capture the latent construct, i.e. board's CSR orientation, we use three board attributes as indicators: board independence (i.e. proportion of outside director representation on board), board gender diversity, and financial expertise on audit committee. Below we discuss the rationale for inclusion of each of these variables.

Board independence. From the agency theory perspective, to reduce opportunism and agency costs, boards should consist of a greater proportion of outside directors. With a greater proportion of outsiders, a board is likely to be more independent and objective in its decision making as well as have greater monitoring potential (Fama and Jensen 1983). Outside directors can monitor the behavior of managers and intervene when managers behave opportunistically (Post et al. 2011). For example, inside directors tend to be more attentive than outsiders to short-term economic performance goals, while outsiders may feel that attending to the environmental and social issues is in the best long-term interest of shareholders (Johnson and Greening 1999). From a resource dependence theory perspective, Pfeffer and Salancik (1978) suggest that the selection of a greater number of independent directors signals a firm's intent to pay greater attention to its external environment and legitimacy. Furthermore, Wang and Dewhirst (1992) and Mallin and Michelon (2011) consider outside directors to be boundary spanners who can attract valuable resources to a firm as well as help a firm establish external links with stakeholders and other organizations. According to Galbreath (2010), board independence could help challenge existing mental models in board decision making, bringing in new insights and perspectives related to environmental and social stakeholders. Accordingly, we argue that there is a positive association between the board independence and its CSR orientation. Asset 4 the database 
used in this study (discussed in detail in the next section) measures board independence by the percentage of independent board members as reported by a company.

Women on board. There is a growing societal as well as regulatory pressure (see Financial Reporting Council 2011) that to gain social legitimacy, boards should represent the population they serve and thus should become more diverse and inclusive (Hillman et al. 2002). According to the 2013 Cranfield Female FTSE Board Report, women make up 5.8\% $(5.4 \%)$ of executive and $21.8 \%(16.6 \%)$ of non-executive directors on FTSE 100 (FTSE 250) companies (Sealy and Vinnicombe 2013). In addition to enhancing social legitimacy, both theory and empirical evidence suggests that women may bring a number of competencies and stakeholder related values to a corporate board. Hillman et al. (2002) compare the educational and occupational background of women and racial minority directors with white American directors and find women directors to be more highly educated than their white male counterparts. Women are also more likely to be support specialists or community influential rather than business experts (categorizations developed by Hillman et al. 2000), due to their often non-conventional career paths. Singh et al. (2006) also find that women are more likely to possess community related expertise. Kramer et al. (2006) find that the presence of women on boards tends to broaden the content of boardroom discussion to include the perspectives of multiple stakeholders. A recent comprehensive literature review of women on corporate boards also draws the conclusion that most research on the role of women on boards is focused around their potential role in building fairer and more inclusive business institutions that reflect the expectations of present generation of stakeholders (Terjesen et al. 2009). Nielsen and Huse (2010) draw upon theories of gender differences and group effectiveness to examine the contribution of women on boards of directors. Their findings suggest that women on boards tend to accept others' positions, support others, and contribute to solving of relational and interpersonal problems. Hence they conclude that 'women may be particularly 
sensitive to - and may exercise influence on - decisions pertaining to certain organizational practices, such as corporate social responsibility and environmental politics' (Nielsen and Huse 2010, p. 138). The Financial Reporting Council (2011) consultation document on gender diversity also echoes the expectation that women on boards may help companies build better relationships with its key stakeholders like customers and employees. Overall, both theoretical arguments and empirical evidence on the role of women on boards suggest that they are more likely to be sensitive to the expectations of stakeholders other than shareholders. Hence we expect presence of women on the board to be positively associated with CSR orientation. Asset4 measures board diversity as percentage of women on the board of directors.

Financial expertise on audit committee. The UK Combined Code (2003), consistent with the recommendations of the Sarbanes Oxley Act (2002) in US (which is used by Asset4 for measuring audit committee expertise), suggests that at least some members of audit committees should have adequate knowledge of finance and financial matters. In UK, as in other countries, audit committees are responsible for monitoring the integrity of the financial statements of the company and for the oversight of the company's systems of internal control and risk management (FRC 2010). Consistent with the expectations, research finds that appropriately staffed audit committees (in terms of having independent non-executives and especially financial experts sitting on them) perform a better oversight function and help enhance firm value (Chan and Li 2008). Recently, Khan et al. (2013) find the presence of an audit committee to have a positive impact on CSR disclosures. As environmental risks can have significant financial implications in the form of environmental fines as well as potential cash outlays for pollution control and for investments in environmentally friendly technologies (Freedman and Patten 2004), audit committees with members having financial expertise are likely to be better equipped for advising the board on developing policies and 
strategies that can help avoid and manage these risks. In this regard, Goodstein and Boeker (1991) state that the specific and unique individual competencies of board directors contribute differently to the board process and priorities, thus motivating management to adopt specific strategies and actions. Hence, financial experts on audit committees can be regarded as what Hillman et al. (2000, p. 241) categorize as 'support specialists' that is "directors who provide expertise and linkages in specific, identifiable areas that support the firm's strategies." Members of audit committees with financial expertise can thus help a firm better assess its CSR-related financial and regulatory risks and help the management develop effective CSR related risk management and reporting strategies. For example, to improve CSR reporting quality financial experts on audit committees can encourage firms to comply with Global Reporting Initiative (GRI) guidelines in environmental and social reporting, integrate their financial and non-financial reporting, and encourage firms to get an external audit of a firm's CSR report. Research suggests that such an audit is valued highly by investors (Lee and Hutchison 2005). Asset4 measures audit committee expertise as a dummy variable with a score 1 if a company has an audit committee with at least three members, one of whom is considered as a 'financial expert' within the meaning of Sarbanes-Oxley, and 0 otherwise.

Board CSR Strategy. Relatively little research has specifically identified variables that could capture a firm's board level strategic stance towards its CSR-related responsibilities. A notable exception is the study by Galbreath (2010), who uses five dimensions developed by the California Environmental Resources Evaluation System (CERES) to demonstrate a firm's governance practices to address climate change. Asset 4 develops an index for capturing a firm's board level CSR policy and strategy based on measures that are closely aligned with those used by Galbreath (2010). These measures are: 1) decision to establish a separate CSR committee; 2) decision to comply with GRI guidelines; 3) decision to have an external audit 
of the firm's CSR report; 4) decision to integrate the firm's financial and extra-financial reporting; and 5) decision to report on the firm's CSR-related global activities. It can argued that the more of these measures a firm adopts, the more proactive and comprehensive is its board level CSR planning, oversight, and communication strategy. First, having a separate CSR committee not only indicates a public recognition of the importance of environmental and social responsibilities for the firm at the top i.e. the 'symbolic' reputational role that these committees play (Rodrigue et al. 2013), but it can also constitute a real commitment of board level human resources and organizational structures, that can enable effective planning and oversight in this area thus contributing to better CSR performance. According to Mackenzie (2007), CSR committees play an important role in assisting the management in CSR strategy formulation and in reviewing the firm's CSR performance. In his review of the terms of reference of CSR committees in UK corporations, he finds that 10 out of 11 mention their task as establishing CSR policies and standards. He cites Rio Tinto's Report for 2004 as an example: "The purpose of the committee is to ensure that Rio Tinto management has in place the policies, standards, systems and people required to meet Group social and environmental commitments" (Mackenzie 2007, p. 939). The interviews of board members by Rodrigue et al. (2013) confirm this function of such committees, as the following quote of one interviewee from their study reveals: "the committee makes sure to tell the board: 'Here it is, we conducted a diligent review,... Everything is under control, except here, except there, and we will follow up"' (Rodrigue et al. 2013, p. 123). Consistent with this expectation of the instrumental/advisory role of CSR committees in improving CSR performance, Mallin and Michelon (2011) find a positive link between the presence of such board committees and measures of corporate social performance.

Second, the decision of companies to adhere to GRI guidelines can be interpreted as a commitment on the part of firms to improve their CSR performance as well as the 
measurement of this performance. This expectation is in line with the finding of Larsen (2007) who reports that the introduction of the legislation that mandated Danish companies to publish 'green accounts' led to companies actually improving their environmental management systems (in term of environmental impact reduction and efficiency). Citing the case of one Danish company that considered its environmental reporting as a strategic decision, Larsen (2007, p. 284) notes that "the company wanted easier access to environmental information because of a strategic decision of improving their internal environmental efficiency, and because they expect easier access to valid information to be of great importance to their future competitiveness." Hence, committing to GRI guidelines can enable a firm to systematic and consistent production and reporting of its environmental performance data. This in turn can allow the firm and its stakeholders to track the development of the firm's CSR performance over time, thus helping enhance its competitiveness as well as stakeholder accountability. In this last regard, Clarkson et al. (2008) note the importance of compliance with GRI guidelines in reporting, if firms are to gain credibility among their various stakeholders.

Third, the decision to have the CSR report externally audited demonstrates a further commitment on the part of the firm to building trust with its stakeholders. Lee and Hutchison (2005) suggest that for gaining credibility investors demand CSR disclosures of firms to be externally audited. Fourth, the decision to integrate financial and extra financial reporting can be seen as an effort by the firm to increase its accountability on the social and environmental impacts of its operations (Eccles and Krzus 2010). Finally, a voluntary decision to report on their global CSR activities suggests commitment on the part of firms to enhance the transparency and disclosure of its global CSR related performance, thus promoting stakeholder engagement and helping build trust with its stakeholders. The importance of reporting CSR responsibility in a global context is well highlighted by this quote of an 
interviewee from the study of Rodigue et al. (2013): "it has become clear from the globalization, it's a very small world, it's very easy for people to get objections mobilized [...]. And so that can impair a company's ability to operate, it can affect your reputation, so a small problem in one part of the world can become a big problem in another part of the world" (Rodrigue et al. 2013, p. 121).

We thus use the Asset4 vision and strategy score to capture a firm's CSR strategy. According to Asset4, the aggregated vision and strategy score "measures a company's commitment and effectiveness towards the creation of an overarching vision and strategy integrating financial and extra-financial aspects. It reflects a company's capacity to convincingly show and communicate that it integrates the economic (financial), social and environmental dimensions into its day-to-day decision-making processes." It is thus reasonable to argue that the more of these strategy and policy measures that a firm adopts that is the higher its vision and strategy score, the more proactive and comprehensive (in terms of internal competencies and external reputation building measures) is its board-level CSR strategy. Further, the more comprehensive and proactive a firm's board CSR strategy is, the better its CSR performance is likely to be.

Environmental and Social Performance Scores. The environmental score as defined by Asset4 "measures a company's impact on living and non-living natural systems, including the air, land and water, as well as complete ecosystems. It reflects how well a company uses best management practices to avoid environmental risks and capitalize on environmental opportunities". It covers 'hard' performance indicators (as classified by Clarkson et al. 2008) such as information on energy used, $\mathrm{CO} 2$ emissions, water and waste recycled, and spills and pollution controversies. Hence, the aggregate environmental score can be considered to provide a largely objective measure of a firm's overall environmental performance. The social score as defined by Asset4 "measures a company's capacity to generate trust and loyalty with its workforce, customers and society, through its use of best management 
practices". It covers issues like employee turnover, accidents, training hours, donations, and health and safety controversies. Social score also covers mostly 'hard' performance indicators (as defined by Clarkson et al. 2008) thus providing a largely objective measure of a firm's social performance.

The Model

Employing the structural equation modelling (SEM) procedure, we simultaneously test the three interconnected hypotheses, as per Figure 2, via the following system of three equations:

$\mathrm{CSR}_{\text {strategy }} \mathrm{it}=\mathrm{f}\left(\right.$ Board CSR orientation $_{\mathrm{it}}$, Slack $_{\mathrm{it}}$, Firm size $\left._{\mathrm{it}}\right)$

Environmental or social performance $_{i t}=\mathrm{f}\left(\mathrm{CSR}\right.$ strategy ${ }_{i t}$, Firm size $_{i t}$,

Profitability $_{i t}$, Capital expenditure ${ }_{i t}$, Block shareholdings $_{i t}$ )

Board CSR orientation $_{i t}=\mathrm{f}\left(\right.$ Environmental or social performance $_{\mathrm{it}}$, Firm size $_{\mathrm{it}}$,

Block shareholdings ${ }_{i t}$, Board duality ${ }_{i t}$ )

The structural equation modelling (SEM) procedure incorporated in Stata13 allows us to both employ latent (unobserved) constructs and estimate the effects of a number of dependent variables simultaneously affecting each other. Due to its ability to take into account at the same time both the simultaneity and the measurement issues (Bollen 1989), we argue that, the SEM approach is more adequate in the context of our study, compared with other techniques which could be used to tackle the problem of endogeneity (e.g. instrumental variable approach, cf. Cheng et al. 2014).

We follow the related extant literature (e.g. Mallin et al. 2013) and employ root mean squared error of approximation (RMSEA), comparative fit index (CFI), and normed fit index (NFI) as the criteria for assessing the goodness of fit of our models. RMSEA tells how well 
the model with unknown but optimally chosen parameter estimates would fit the population's covariance matrix (Byrne 1998). CFI and NFI compare the model with the 'worst case scenario' of a null model with all the variables being uncorrelated (Bentler 1990). The aforementioned measures have been argued to be both reliable and informative in empirical research (Mallin et al. 2013). While analyzing the goodness of fit measures, we use the cutoff values recommended by prior studies and deem the fit of a model to be acceptable if both CFI and NFI index values exceed 90\% and RMSEA is smaller than .07 (Mallin et al. 2013; Steiger 2007).

Exogenous Regressors and Control Variables

Control variables used in each of the above equation are based largely on prior related empirical evidence. In Equation (1), CSR strategy is likely to be affected not just by board CSR orientation, but also the availability of financial slack and firm size. Clarkson et al. (2011) argue and find empirical support for the claim that firms pursuing a proactive environmental strategy are the ones with greater financial resources. Similar results on the role of financial slack in enabling pursuit of CSR oriented goals is found by Arora and Dharwadkar (2011) and Harrison and Coombs (2012). Hence, we expect a positive relation between CSR strategy and financial slack. Scholars have argued that larger firms face greater stakeholder responsibility pressures (Brammer and Pavelin 2006; 2008; Cho and Patten 2007; Mallin and Michelon 2011, Mallin et al. 2013) as well as higher litigation risks (Clarkson et al. 2011). Accordingly we expect CSR strategy to be positively related to firm size.

In Equation (2), where we model environmental and social performance, we follow prior evidence and control for firm size, profitability, and block shareholdings. Consistent with prior arguments and empirical evidence (Clarkson et al. 2011; Ioannou and Serafeim 2012; Johnson and Greening 1999; Mallin and Michelon 2011; Mallin et al. 2013), we expect 
a positive association of firm size and profitability with both measures of CSR performance. There is a theoretical argument (Johnson and Greening 1999) that large block holders, due to their narrow short term share performance targets and illiquidity of holdings, may tend to focus on short term returns, whereas investments in CSR require longer time horizons. Recent empirical evidence supports this argument (Ioannou and Serafeim 2012). Accordingly we expect a negative relation between block holdings (measured as block holdings of 5\% or more) and measures of environmental and social performance. Clarkson et al. (2011) argue that firms making higher capital expenditures are likely to have newer, more resource efficient equipment. Accordingly we account for capital expenditures in determining environmental and social performance.

In Equation (3), in addition to environmental and social performance, we expect board CSR orientation to be positively related to firm size. As argued earlier, larger firms face greater public scrutiny as well as stakeholder responsibility pressures. Thus, they are more likely to have board members with CSR orientation. Moreover as argued earlier, block equity holders are more likely to be shareholder centric, thus less inclined to appoint board members with CSR orientation. Finally CEOs holding a chair position (i.e. duality), are likely to favor a CEO friendly board, thus less likely to favor outsiders on the board. There is evidence which suggests that powerful CEOs (such as those holding CEO and chairman position in our case) tend to select less independent members on the board (Shivdasani and Yermack 1999). Accordingly we expect a negative relation between duality and board CSR orientation.

In terms of measurement of control variables, firm size is measured by natural logarithm of net sales (Mallin and Michelon 2011). Following Arora and Dharwadkar (2011) we employ a slack measure defined as the ratio of the sum of cash and short-term investments and total receivables to the book value of total assets. Profitability is measured by return on equity (ROE), following Mallin and Michelon (2011) and Mallin et al. (2013). Capital 
expenditure is measured as the ratio of capital expenditures to net sales (Mallin and Michelon 2011). Block shareholdings are measured as holdings of 5\% or more (Agarwal and Knoeber 1996). Duality is an indicator variable equal to 1 if the CEO simultaneously chairs the board and 0 otherwise.

\section{Sample and Data}

The sample is the intersection of the Asset4 and Datastream universe of UK listed companies, covering the period 2002-2010. Asset4 is the database used for obtaining environmental, social and governance data, while Datastream is the source for all financial data. The intersection of these data sets yields a usable sample of 2028 firm-year observations. This is mainly due to the limited coverage by Asset4. Industries are classified by using the FTSE/DJ single-digit Industry Classification Benchmark (ICB) March 2008 version. This leads to 10 industry groups in the sample: oil and gas, basic materials, industrials, consumer goods, health care, consumer services, telecommunications, utilities, financials and technology. Table 1 gives the break-up of industries covered in the sample for each year. Table 1 shows that general industrials, consumer services and financials account for the bulk of companies in the sample. The industrials classification includes mostly heavy manufacturing industries

like construction and building materials, defense and aerospace, and other industrial engineering industries like electrical components and equipment, and electronic equipment. Consumer services include food and drug retailers, general retailers, media, and travel and leisure industries. Financials include banks, insurances, real estate and financial services. In short, the sample represents a wide range of industries.

[Insert Table 1 about here] 
The Asset4 dataset with environmental, social, and governance scores is used in this study. Asset4, a Thomson Reuters business, provides largely objective, relevant and systematic environmental (E), social (S) and governance (G) information primarily for use by professional investors and corporate executives. ESG scores are based on 900 individual data points used as inputs to calculate 250 key performance indicators, further organized into 15 categories within the three E, S, and G pillars: environmental (3 categories: emissions reduction, resource reduction, and product innovation), social (7 categories: employment quality, health and safety, training and development, diversity, human rights, community and product responsibility), and governance (5 categories: board structure, board function, compensation policy, shareholder rights, and vision and strategy). The key performance indicators, categories, and pillars from Asset4 are equally weighted calculations of relative company performance, the benchmark being the Asset4 company universe. These ratings are Z-scored, thus benchmarking the performance of each firm with the rest of the firms in the universe. The primary data used has to be publicly available and typical sources include stock exchange filings, CSR and annual reports, non-governmental organization websites and various news sources. In this study we use the aggregate environmental and social scores incorporating all categories and key performance indicators. However, given the focus of this study, we use only the relevant governance performance indicators, namely those related to board structure and board vision and strategy.

A number of recent studies have adopted Asset4 ESG dataset to measure firms' environmental, social and governance performance (e.g. Cheng et al. 2014; Ioannou and Serafeim 2012; Kocmnova et al. 2011). In comparison with the KLD database for US companies widely used in the CSR literature, Asset4 provides more comprehensive calculation of the rating scores. Humphrey et al. (2012) mention several issues with KLD's binary rating system which involves examining a firm's corporate social performance (CSP) 
strengths and concerns: a firm is given a score of 0 or 1 across each strength or concern. They cite the case of hazardous waste production as an example. First, the binary ratings do not distinguish between the levels of hazardous waste production. Second, firms in heavy polluting industries like oil and gas have lower KLD score than other firms that have very limited or no disclosure to producing hazardous waste, regardless of how well the firm manages its hazardous waste. By definition then, the KLD ratings system is biased toward a higher concern score for those industries that disclose information about their environmental concerns. Thus, Humphrey et al. (2012) point out that the number of measures within each of KLD's dimensions can skew overall CSP scores.

\section{Empirical Analysis and Results}

Descriptive Statistics and Correlations

[Insert Table 2 about here]

Table 2 reports the descriptive statistics for all variables used in our analyses. The mean values of environmental and social performance scores are $59 \%$ and $63 \%$, respectively. About $52 \%$ of the board members of an average firm are independent, while about $4 \%$ of the firms have the same person as CEO and Chairman (i.e. duality). On average about $8 \%$ of board members are women. $65 \%$ of audit committees have relevant expertise (i.e. with at least one member being considered a 'financial expert' within the meaning of SarbanesOxley given his or her extensive experience in accounting and auditing matters). The mean value of CSR strategy score is $62 \%$. The average firm size measured as natural logarithm of net sales is 14.05 , which is equivalent to sales value of approximately GBP 1.3 billion. The mean values of profitability, capital expenditure and block shareholdings are $25 \%, 15 \%$, and $26 \%$, respectively. The average slack resources available in a firm correspond to $12 \%$ of the 
book value of total assets. Table 3 displays the pairwise correlations for all variables. Given the relatively moderate levels of correlations among most variables, multi-collinearity is not likely to be a problem for our analyses.

[Insert Tables 3 and 4 about here]

\section{SEM Results}

Table 4 reports the results of structural equation modelling with respect to environmental performance. All three indicators fall within the desirable ranges $(\mathrm{RMSEA}=.068, \mathrm{CFI}=.919$, NFI $=.912$ ) indicating acceptable goodness of fit for the corresponding model. Importantly, Table 4 supports all of our three hypotheses. Specifically, we find that boards which are more CSR oriented tend to show greater commitment to CSR by developing a more proactive and comprehensive board CSR strategy, which in turn allows them to achieve superior environmental performance. Moreover, superior environmental performers also tend to choose more CSR-conducive board attributes. Hence, our findings suggest the existence of a cyclical link among a firm's board CSR orientation, board CSR strategy, and its environmental performance. The aforementioned relationships are not only statistically significant, but also economically meaningful. In particular, one standard deviation increase in board CSR orientation leads to an increase of CSR strategy by about $22 \%$ of the respective standard deviation $(\beta=.216, \mathrm{p}<.001)$. One standard deviation increase in CSR strategy boosts environmental performance by almost $54 \%$ of the respective standard deviation ( $\beta$ $=.539, \mathrm{p}<.001)$. Finally, one standard deviation increase in environmental performance enhances board CSR orientation to somewhat smaller extent, i.e. by $15 \%$ of the respective standard deviation $(\beta=.152, \mathrm{p}<.001)$. The results of Table 4 also show that, in our measurement model, loadings corresponding to all three indicators for board CSR orientation, 
namely board independence $(\beta=.552, \mathrm{p}<.001)$, gender diversity $(\beta=.369, \mathrm{p}<.001)$, and audit committee expertise $(\beta=.442, \mathrm{p}<.001)$ are highly significant and have correct signs.

The results with respect to control variables in Table 4 are as expected. Consistent with prior literature (e.g. Clarkson et al. 2011; Ioannou and Serafeim 2012), firm size is positively linked with CSR strategy $(\beta=.382, \mathrm{p}<.001)$, environmental performance $(\beta$ $=.251, \mathrm{p}<.001)$, and board CSR orientation $(\beta=.278, \mathrm{p}<.001)$. This indicates that since larger, more visible firms tend to face greater pressure from a variety of external stakeholders (Deegan 2002; Patten 2002), they have incentives to improve their environmental performance as well as to strengthen their board CSR orientation. Consistent with prior related literature (Ioannou and Serafeim 2012) we find block shareholdings to be negatively related to environmental performance $(\beta=-.094, \mathrm{p}<.001)$ and board CSR orientation $(\beta=-$ $.462, \mathrm{p}<.001)$, suggesting that large shareholders in a firm tend to be more interested in shareholder, and less interested in other stakeholder interests. Contrary to our expectations but consistent with the findings of Mallin and Michelon (2011), we find no link between firm profitability (i.e. ROE) and environmental performance. Capital expenditure consistent with previous findings (Clarkson et al. 2011) is positively linked with environmental performance $(\beta=.047, \mathrm{p}<.01)$, suggesting that in general firms are now investing in environmentally friendly technologies.

[Insert Table 5 about here]

Table 5 reports the results of structural equation modelling with respect to social performance. The corresponding model fit is again satisfactory $(\mathrm{RMSEA}=.068, \mathrm{CFI}=.919, \mathrm{NFI}=.912)$ and, overall, the results are very similar to those in Table 4, corroborating our hypotheses for social performance as well. In terms of control variables, a notable difference between Tables 4 and 5 is that the coefficient on capital expenditure is not significant in Table 5, indicating 
that capital expenditure does not affect a firm's social performance. This is not entirely surprising, given that better social performance is likely to be less financial capital sensitive, but more human relational capital sensitive.

\section{Sensitivity Analyses}

To test the robustness of the above results, we run a number of sensitivity tests. In the interest of brevity, below we just summarize key findings without reporting the corresponding model estimates in the paper.

First, in panel data set like ours it is possible that observations corresponding to the same firms over years may not be independent. In order to account for such a possibility, we cluster standard errors at firm level and re-estimate models reported in Tables 4 and 5. While the clustering procedure precludes the computation of the model fit measures, it allows us to corroborate the conclusions by examining the adjusted standard errors of the estimates and resulting significance levels. In short, while z-statistics for many of the coefficients are lower in the case of the models involving clustering of standard errors, all the coefficients significant in the base model specifications retain their significance in models involving clustering. Importantly, all three coefficients corresponding to the hypothesized effects of the three endogenous variables remain significant at $1.5 \%$ or better in the models including either environmental or social performance, further corroborating Hypotheses 1-3.

Second, prior studies indicate that environmental responsibility is influenced by the nature of business activities, particularly by industry sectors most closely associated with environmental concerns (Brammer and Pavelin 2008). We thus amend our model specifications and include industry fixed effects in the equations explaining environmental or social performance. While the goodness of fit for the resulting models is somewhat weaker than for those reported in Tables 4 and 5, the relationships stipulated by our hypotheses 
remain highly significant. Importantly, while we do find evidence of differences in CSR performance across industries, there is also variation in significance of the industry fixed effects between models including environmental and social performance. This finding is in line with Cormier et al.'s (2011) suggestion that it is important to distinguish environmental performance from social performance in CSR related studies.

Finally, we examine the effect of inclusion of year fixed effects. Again, while the fit indices for the resulting models are somewhat weaker than before, the relationships stipulated by our hypotheses remain highly significant.

At this point it is worth noting one limitation of our sample. As the main clientele of Asset 4 are investors, particularly large investors, our analysis reveals that firms covered by Asset4 differ systematically from those in the universe of FTSE all share companies. Specifically we find that companies covered by Asset 4 tend to be larger, have more slack resources and higher capital expenditures. Moreover, the database coverage tends to improve towards the final years of the sample. However, we find no evidence of industry bias in our sample. These database limitations may somewhat limit the generalizability of our results.

\section{Conclusions and Implications}

\section{Conclusions}

In this study drawing upon the theoretical insights from the management and corporate governance related CSR literature, specifically the RBV and the RDT theories, we develop and test a theoretical model that makes explicit the proposed endogenous links between board CSR orientation, board CSR strategy, and corporate environmental and social performance. The empirical analysis based on the proposed theoretical model, suggests that firms with 
more CSR oriented boards (i.e. those with more independent directors, women directors as well as directors possessing financial expertise sitting on the audit committee) are more likely to develop a proactive and comprehensive board CSR strategy (i.e. one which combines internal organizational competencies with external reputation building measures). Such firms in turn are more likely to achieve superior environmental and social performance. Moreover, we find this link to be endogenous and self-reinforcing, with firms having superior environmental and social performance, further strengthening their board level CSR orientation.

These findings lend support to both RBV as well as RDT theory based predictions on the linkages between boards, their strategies and their desired performance outcomes. According to the CSR-related RBV theory (Hart 1995), a board and its composition could be seen as a unique, internal, tacit and socially complex competitive resource which can help a firm develop, implement and communicate CSR strategies that promote superior environmental and social performance. While prior studies drawing on RBV theory, have highlighted the role of the top decision makers and their strategies in achieving superior environmental performance (e.g. Al-Tuwaijri et al. 2004; Clarkson et al. 2011), ours to the best of our knowledge is the first that makes explicit the desired board attributes and the effective board level CSR strategies. Moreover, our finding of a cyclical link lends support to the key RBV theory prediction that in order to sustain competitive advantages in the field of CSR, proactive CSR oriented firms tend to keep building on their unique internal CSR competencies and resources (Hart 1995).

Studies in the CSR literature that draw on the RDT theory, tend to assume the link to run from board CSR attributes to firm CSR performance, thus treating board attributes as exogenous (e.g. Mallin and Michelon 2011). Such treatment can lead to misleading interpretations. On theoretical as well as empirical level, RDT scholars (Pfeffer 1973; 
Hillman et al. 2000) see the board composition as a response to the external challenges that a firm may face. Hence, the RDT theory predicts that both the board's CSR-conducive composition and the firm CSR performance should be simultaneously determined by these social and natural environmental challenges. As our theoretical model and empirical findings suggest, ignoring these theoretical and empirical insights could have misleading research and policy implications.

Implications

The findings of this paper would be of interest to a number of constituencies. For corporate managers, our findings reinforce earlier suggestions in the literature that CSR may not be a viable strategy for all firms (Clarkson et al. 2011). The results shed light on the combination of human (at board level) and organizational (e.g. presence of a formal CSR committee) resources, which can help firms achieve superior CSR performance. Our findings also suggest that it is the larger firms that are best positioned to allocate and sustain these resource commitments.

For research scholars, the theoretical model and empirical approach developed in this paper can be applied to guide any future investigation of the board characteristics-conductperformance type analysis be it in the field of CSR or corporate governance in general. Recent reviews of the literature on corporate boards by Adams et al. (2010) and Johnson et al. (2013) re-emphasize the importance of addressing the endogeneity concern as well as the need to move beyond attributes-performance type analysis and incorporate explicitly the mechanisms through which director attributes may affect firm performance outcomes. Our analytical approach provide among the first steps in this direction. Future research could build upon it by considering additional board characteristics and decisions as well as studying various aspects of company performance in addition to CSR outcomes. Moreover, while the 
setup proposed here addresses the issue of simultaneity, the proposed model is static in nature. Development and testing of a dynamic model incorporating intertemporal relationships between board attributes, board actions, and corporate performance would be an interesting yet challenging avenue for future research.

For policy makers, our findings of a positive cyclical link between board CSR attributes, CSR strategies, and CSR performance are particularly relevant as these raise concerns about how firms are using their strategic competitive advantages (particularly in the field of environmental responsibility). This cyclical link is indicative of a widening gap between the leaders and laggards in CSR. The business case for CSR (empirical support for which is now relatively abundant in the literature, see van Beurden and Gossling's 2008 review) rests on the premise that firms can 'do well by doing good'. There are two issues to consider in this respect: First 'doing well' i.e. making economic profits through CSR activities often entail that firms should turn the CSR 'threats' they face, into business opportunities that allow for extracting economic rents. This is particularly true for environmental threats where the concern about looming regulation has prompted particularly the larger corporations to take pre-emptive measures in the environmental arena to gain competitive advantages vis-à-vis their smaller competitors, thus squeezing out competition. To illustrate this point, Devinney (2009, p. 50) cites the example where "one small mining company accused its global competitor of using its 'award winning CSR positioning' to disadvantage competitors by lobbying for standards that reduced the value of the small mining companies (which did not have the scale to absorb the costs of the new standards) so that it could purchase them at a discount." This leads us to the second issue: is this really 'doing good' and if so, for whom? Corporations have multiple stakeholders and multiple responsibilities that may often involve trade-offs. Hence policy makers when designing regulation, need to be cognizant of how 
social and environmental regulation may affect different corporate stakeholders and how firms may use their competitive advantages in the field of CSR.

\section{Acknowledgements}

We would like to express our gratitude to Professor Thomas Clarke (Section Editor) and a number of anonymous reviewers for their very valuable comments on all the earlier versions of the manuscript. Their insightful input has helped us greatly to shape and improve the paper. We would also like to acknowledge the insightful feedback and suggestions received on earlier versions of this work from Professor Timothy M. Devinney and from the participants of various conferences and seminars where earlier versions of the paper have been presented.

\section{References}

Adams, R.B., Hermalin, B.E., \& Weisbach, M.S. (2010). The role of boards of directors in corporate governance: A conceptual framework \& survey. Journal of Economic Literature, 48(1), 59-108.

Agrawal, A. \& Knoeber, C. (1996). Firm performance and mechanisms to control agency problems between managers and shareholders. Journal of Financial and Quantitative Analysis, 31(3), 377-397.

Aguilera, R., Rupp, D., Williams, C. \& Ganapathi, J. (2007). Putting the S back in corporate social responsibility: A multilevel theory of social change in organizations. Academy of Management Review, 32(3), 836-863.

Al-Tuwaijri, S.A., Christensen, T.E. \& Hughes, K.E. (2004). The relations among environmental disclosure, environmental performance, and economic performance: A 
simultaneous equations approach. Accounting, Organizations and Society, 29(5-6), $447-471$.

Arora, P. \& Dharwadkar, R. (2011). Corporate governance and corporate social responsibility (CSR): The moderating roles of attainment discrepancy and organization slack. Corporate Governance: An International Review, 19(2), 136-152.

Bentler, P.M. (1990). Comparative Fit Indexes in Structural Models. Psychological Bulletin, 107(2), 238-246.

Bollen, K.A. (1989). Structural Equations with Latent Variables. John Wiley \& Sons, New York, NY.

Boyd, B. (1990). Corporate linkages and organizational environment: A test of the resource dependence model. Strategic Management Journal, 11(6), 419-430.

Brammer, S. \& Pavelin, S. (2006). Voluntary environmental disclosures by large UK companies. Journal of Business Finance and Accounting, 33(7-8), 1168-1188.

Brammer, S. \& Pavelin, S. (2008). Factors influencing the quality of corporate environmental disclosure. Business Strategy and the Environment, 17(2), 120-136.

Byrne, B.M. (1998). Structural Equation Modeling with LISREL, PRELIS and SIMPLIS: Basic Concepts, Applications and Programming. Lawrence Erlbaum Associates, Mahwah, NJ.

Chan, K.C., \& Li, J. (2008). Audit committee and firm value: Evidence on outside top executives as expert-independent directors. Corporate Governance: An International Review, 16(1), 16-31.

Cheng, B., Ioannou, I. \& Serafeim, G. (2014). Corporate sustainability and access to finance. Strategic Management Journal, 35(1), 1-23.

Cho, C. \& Patten, D.M. (2007). The role of environmental disclosures as tools of legitimacy: A research note. Accounting, Organizations and Society, 32(7-8), 639-647. 
Clarkson, P.M., Li, Y., Richardson, G.D. \& Vasvari, F.P. (2008). Revisiting the relation between environmental performance and environmental disclosure: An empirical analysis. Accounting, Organizations and Society, 33(4-5), 303-327.

Clarkson, P.M., Li, Y., Richardson, G.D. \& Vasvari, F.P. (2011). Does it really pay to be green? Determinants and consequences of proactive environmental strategies. Journal of Accounting and Public Policy, 30(2), 122-144.

Companies Act. (2006). Office of Public Service Information, London.

Cormier, D., Ledoux, M. \& Magnan, M. (2011). The informational contribution of social and environmental disclosures for investors. Management Decision, 49(8), 1276-1304.

Deegan, C. (2002). The legitimising effect of social and environmental disclosures - A theoretical foundation. Accounting, Auditing \& Accountability Journal, 15(3), 281311.

Devinney, T.M. (2009). Is the socially responsible corporation a myth? The good, the bad and the ugly of corporate social responsibility. Academy of Management Perspectives, 23(5), 44-56.

Eccles, R.G. \& Krzus, M. (2010). One Report: Integrated Reporting for a Sustainable Strategy. John Wiley and Sons, Inc., New York, NY.

Fama, E. \& Jensen, M. (1983). Separation of ownership and control, Journal of Law and Economics, 26(2), 301-325.

Financial Reporting Council. (2003). The combined code on corporate governance. London: Financial Reporting Council.

Financial Reporting Council, (2010). Guidance on Audit Committees, available at http://www.frc.org.uk/Our-Work/Publications/Corporate-Governance/Guidance-onAudit-Committees.aspx [Accessed on 28 Jan 2014] 
Financial Reporting Council, (2011). Consultation document: gender diversity on boards, available from: www.frc.org.uk/images/uploaded/documents/FRC\%20Consultation $\% 20$ Document $\% 2$ 0-\%20Gender\%20Diversity\%20on\%20Boards3.pdf. [Accessed on 2 Dec 2011].

Freedman, M. \& Patten, D.M. (2004). Evidence on the pernicious effect of financial report environmental disclosure. Accounting Forum, 28(1), 27-41.

Galbreath, J. (2010). Corporate governance practices that address climate change: An exploratory study. Business Strategy and the Environment, 19(5), 335-350.

Goodstein, J. \& Boeker, W. (1991). Turbulence at the top: A new perspective on governance structure changes and strategic change. Academy of Management Journal, 34(2), 306330.

Hambrick, D.C. (2007). Upper echelons theory: An update. Academy of Management Review, $32(2), 334-343$.

Harrison, J. S., \& Coombs, J. E. (2012). The moderating effects from corporate governance characteristics on the relationship between available slack and community-based firm performance. Journal of Business Ethics, 107(4), 409-422.

Hart, S.L. (1995). A natural resource based view of the firm. Academy of Management Review, 20(4), 986-1014.

Hermalin, B.E. \& Weisbach, M.S. (1998). Endogenously chosen boards of directors and their monitoring of the CEO. American Economic Review, 88(1), 96-118.

Hermalin, B.E. \& Weisbach, M.S. (2003). Board of directors as an endogenously determined institution: a survey of the economic literature. Economic Policy Review, 9(1), 7-26.

Hillman, A.J., Cannella, A.A.Jr., \& Harris, I.C. (2002).Women and racial minorities in the boardroom: how do directors differ? Journal of Management, 28(6), 747-763. 
Hillman, J.A., Canella, A.A. \& Paetzold, R.L. (2000). The resource dependence role of corporate directors: strategic adaptation of board composition in response to environmental change. Journal of Management Studies, 37(2), 235-255.

Hillman, A.J. \& Dalziel, T. (2003). Boards of directors and firm performance: integrating agency and resource dependence perspectives. Academy of Management Review, 28(3), 383-396.

Hillman, A.J. \& Keim, G.D. (2001). Shareholder value, stakeholder management and social issues: what's the bottom line? Strategic Management Journal, 22(2), 125-139.

Humphrey, J.E., Lee, D.D. \& Shen, Y. (2012). Does it cost to be sustainable? Journal of Corporate Finance, 18(3), 626-639

Ioannou, I. \& Serafeim, G. (2012). What drives corporate social performance? The role of nation-level institutions. Journal of International Business Studies, 43(9), 834-864.

Jamali, D., Safieddine, A.M. \& Rabbath, M. (2008). Corporate governance and corporate social responsibility synergies and interrelationships. Corporate Governance: An International Review, 16(5), 443-459.

Jensen, M.C. \& Meckling, W. (1976) Theory of firm: Managerial behaviour, agency costs, and capital structure. Journal of Financial Economics, 3(4), 305-360.

Jensen, M.C. (2002). Value maximization, stakeholder theory, and the corporate objective function. Business Ethics Quarterly, 12(2), 235-256.

Jo, H. \& Harjoto, M.A. (2011). Corporate governance and firm value: The impact of corporate social responsibility. Journal of Business Ethics, 103(3), 351-383.

Jo, H. \& Harjoto, M.A. (2012), The causal effect of corporate governance on corporate social responsibility. Journal of Business Ethics, 106(1), 53-72. 
Johnson, R.A. \& Greening, D.W. (1999). The effects of corporate governance and institutional ownership types on corporate social performance. Academy of Management Journal, 42(5), 564-576.

Johnson, S. G., Schnatterley, K. \& Hill, A.D. (2013). Board composition beyond independence: social capital, human capital, and demographics. Journal of Management, 39(1), 232-261.

Khan, A., Muttakin, M.B. \& Siddiqui, J. (2013). Corporate governance and corporate social responsibility: Evidence from an emerging economy, Journal of Business Ethics, 114(2), 207-223.

Kocmnova, A., Hrebicek, J. \& Docekalova, M. (2011). Corporate governance and sustainability. Economics and Management, 16, 543-550.

Kramer, V.W., Konrad, A.M. \& Erkut, S. (2006). Critical mass on corporate boards: Why three or more women enhance governance. Wellesley Center for Women's Publications, Wellesley, MA.

Larsen, L.B. (2000). Strategic implication of environmental reporting. Corporate Environmental Strategy, 7(3), 276-287.

Lash, J. and Wellington, F. (2007), Competitive advantage on a warming planet, Harvard Business Review, 85, 94-102.

Lee, T.M. \& Hutchison, P.D. (2005). The decision to disclose environmental information: A research review and agenda. Advances in Accounting, 21, 83-111.

Mackenzie, C. (2007). Boards, incentives and corporate social responsibility: The case for a change of emphasis. Corporate Governance: An International Review, 15(5), 935943. 
Mallin, C.A. \& Michelon, G. (2011). Board reputation attributes and corporate social performance: An empirical investigation of the US Best Corporate Citizens. Accounting and Business Research, 41(2), 119-144.

Mallin, C., Michelon, G. \& Raggi, D. (2013). Monitoring intensity and stakeholders' orientation: How does governance affect social and environmental disclosure, Journal of Business Ethics, 114(1), 29-43.

Nielsen, S. \& Huse, M. (2010). The contribution of women on boards of directors: Going beyond the surface. Corporate Governance: An International Review, 18(2), 136-148.

Patten, D.M. (2002). The relation between environmental performance and environmental disclosure: A research note. Accounting, Organizations and Society, 27(8), 763-764.

Pfeffer, J. (1972). Size and composition of corporate boards of directors: the organization and its environment. Administrative Science Quarterly, 17(2), 218-228.

Pfeffer, J. (1973). Size, composition and function of hospital boards of directors: A study of organisation-environment linkage. Administrative Science Quarterly, 18(3), 349-364.

Pfeffer, J. \& Salancik, G.R. (1978). The external control of organizations: A resource dependence perspective. Harper and Row, New York, NY.

Porter, M.E. \& van der Linde, C. (1995). Green and competitive: Ending the stalemate. Harvard Business Review, 73(5), 120-134.

Porter, M.E., \& Kramer, M. R. (2006). Strategy and society: The link between competitive advantage and corporate social responsibility. Harvard Business Review, 84(12), 7892.

Porter, M.E. \& F.L. Reinhardt. (2007). A strategic approach to climate change, Harvard Business Review, 85(10), 22-23. 
Post, C., Rahman, N. \& Rubow, E. (2011). Green governance: Boards of directors' composition and environmental corporate social responsibility. Business \& Society, $50(1), 189-223$.

Rodrigue, M., Mangan, M., \& Cho, C.H. (2013). Is environmental governance substantive or symbolic? An empirical investigation. Journal of Business Ethics, 114(1), 107-129.

Russo, M.V. \& Fouts, P.A. (1997). A resource-based perspective on corporate environmental performance and profitability. Academy of Management Journal, 40(3), 534-559.

Sarbanes Oxley Act. (2002). Public Law 107-204, 116 STAT. 745-809.

Shivdasani, A. \& Yermack, D. (1999). CEO involvement in the selection of new board members: An empirical analysis. Journal of Finance, 54(5), 1829-1853.

Sealy, R. \& Vinnicombe, S. (2013). The 2013 female FTSE report. Cranfield School of Management, UK.

Singh, V., Vinnicombe, S. \& Kumra, S. (2006). Women in formal corporate networks: An organizational citizenship perspective. Women in Management Review, 21(6), 458482.

Steiger, J.H. (2007), Understanding the limitations of global fit assessment in structural equation modelling. Personality and Individual Differences, 42(5), 893-898.

Terjesen, S., Sealy, R. \& Singh, V. (2009). Women directors on corporate boards: A review and research agenda. Corporate Governance: An International Review, 17(3), 320337.

UK Corporate Governance Code. (2010). The UK corporate governance code. Financial Reporting Council, London.

van Beurden, P., \& Gossling, T. (2008). The worth of values-a literature review on the relation between corporate social and financial performance. Journal of Business Ethics, 82(2), 407-424. 
Wang, J. \& Dewhirst, D.H. (1992), Board of directors and stakeholder orientation, Journal of Business Ethics, 11(2), 115-123.

Webb, E. (2004). An examination of socially responsible firms' board structure. Journal of Management and Governance, 8(3), 255-277. 
TABLE 1

Number of Sample Companies in Each Sector and Each Year

\begin{tabular}{ccccccccccccc}
\hline $\begin{array}{c}\text { Industry } \\
\text { Code }\end{array}$ & Industry & 02 & 03 & 04 & 05 & 06 & 07 & 08 & 09 & 10 & Total & Percent \\
\hline 0001 & Oil \& gas & 4 & 4 & 12 & 13 & 13 & 14 & 14 & 18 & 19 & 111 & 5.47 \\
1000 & Basic materials & 2 & 2 & 14 & 14 & 15 & 18 & 22 & 22 & 22 & 131 & 6.46 \\
2000 & Industrials & 18 & 18 & 53 & 65 & 66 & 67 & 67 & 71 & 67 & 492 & 24.26 \\
3000 & Consumer goods & 9 & 9 & 17 & 22 & 23 & 23 & 23 & 27 & 26 & 179 & 8.83 \\
4000 & Health care & 3 & 3 & 4 & 5 & 5 & 5 & 5 & 9 & 9 & 48 & 2.37 \\
5000 & Consumer services & 21 & 22 & 46 & 54 & 57 & 59 & 59 & 64 & 62 & 444 & 21.89 \\
6000 & Telecommunications & 2 & 2 & 3 & 5 & 5 & 5 & 5 & 5 & 6 & 38 & 1.87 \\
7000 & Utilities & 6 & 6 & 7 & 8 & 8 & 8 & 8 & 8 & 7 & 66 & 3.25 \\
8000 & Financials & 18 & 19 & 49 & 54 & 54 & 60 & 60 & 63 & 60 & 437 & 21.55 \\
9000 & Technology & 2 & 2 & 6 & 10 & 10 & 10 & 10 & 16 & 16 & 82 & 4.04 \\
Total & & 85 & 87 & 211 & 250 & 256 & 269 & 273 & 303 & 294 & 2028 & 100.00 \\
\hline
\end{tabular}


TABLE 2

\section{Descriptive Statistics}

\begin{tabular}{ccccc}
\hline Variable & Mean & S.D. & Min & Max \\
\hline Environmental performance & 59.21 & 27.46 & 9.54 & 97.17 \\
Social performance & 63.40 & 25.97 & 4.18 & 98.82 \\
Board independence & 51.54 & 14.23 & 0 & 100 \\
Board diversity & 7.57 & 9.04 & 0 & 62.5 \\
Audit committee expertise & 0.65 & 0.48 & 0 & 1 \\
Board duality & 0.04 & 0.19 & 0 & 1 \\
CSR strategy & 62.03 & 29.64 & 9.51 & 98.61 \\
Firm size & 14.05 & 1.67 & 7.45 & 19.33 \\
Profitability (ROE) & 0.25 & 1.58 & -9.04 & 58.80 \\
Capital expenditure & 0.15 & 0.52 & 0 & 15.56 \\
Block shareholdings & 0.26 & 0.21 & 0 & 0.91 \\
Slack & 0.12 & 0.13 & 0.00 & 0.87 \\
\hline
\end{tabular}

Note: All variables are as defined in the "Variables and Models" section. 
TABLE 3

Pairwise Correlation Matrix

\begin{tabular}{|c|c|c|c|c|c|c|c|c|c|c|c|c|c|}
\hline & Variable & (1) & (2) & (3) & (4) & (5) & (6) & (7) & $(8)$ & (9) & $(10)$ & $(11)$ & $(12)$ \\
\hline 1 & Environmental performance & 1.00 & & & & & & & & & & & \\
\hline 2 & Social performance & $0.72 * * *$ & 1.00 & & & & & & & & & & \\
\hline 3 & Board independence & $0.27 * * *$ & $0.32 * * *$ & 1.00 & & & & & & & & & \\
\hline 4 & Board diversity & $0.22 * * *$ & $0.25 * * *$ & $0.18 * * *$ & 1.00 & & & & & & & & \\
\hline 5 & Audit committee expertise & $0.17 * * *$ & $0.15^{* * *}$ & $0.27 * * *$ & $0.14^{* * *}$ & 1.00 & & & & & & & \\
\hline 6 & Board duality & $-0.11 * * *$ & $-0.11 * * *$ & $-0.13 * * *$ & 0.02 & -0.01 & 1.00 & & & & & & \\
\hline 8 & Firm size & $0.51 * * *$ & $0.56^{* * *}$ & $0.31 * * *$ & $0.22 * * *$ & $0.10 * * *$ & $-0.08 * * *$ & $0.48 * * *$ & 1.00 & & & & \\
\hline 9 & Profitability & -0.02 & -0.02 & 0.02 & -0.02 & $0.05^{*}$ & -0.01 & 0.00 & -0.01 & 1.00 & & & \\
\hline 10 & Capital expenditure & -0.01 & $-0.09 * * *$ & 0.00 & 0.01 & 0.00 & -0.02 & 0.03 & $-0.28 * * *$ & -0.02 & 1.00 & & \\
\hline 11 & Block shareholdings & $-0.24 * * *$ & $-0.24 * * *$ & $-0.26 * * *$ & $-0.18 * * *$ & $-0.32 * * *$ & $0.11 * * *$ & $-0.18 * * *$ & $-0.20 * * *$ & 0.00 & 0.02 & 1.00 & \\
\hline 12 & Slack & $-0.20 * * *$ & $-0.12 * * *$ & 0.01 & -0.03 & 0.02 & -0.01 & $0.10 * * *$ & $-0.20 * * *$ & $0.04 \uparrow$ & $-0.04 \dagger$ & $0.12 * * *$ & 1.00 \\
\hline
\end{tabular}

Note: All variables are as defined in the "Variables and Models" section.

$\dagger \mathrm{p} .10$

* p.05

$* *$ p .01

$* * * \mathrm{p} .001$. 
TABLE 4

Results of Structural Equation Model with Environmental Performance

\begin{tabular}{|c|c|c|c|c|}
\hline \multicolumn{5}{|c|}{ Structural model: } \\
\hline \multirow[b]{2}{*}{ Independent variable } & \multirow{2}{*}{$\begin{array}{l}\text { Predicted } \\
\text { sign }\end{array}$} & \multicolumn{3}{|c|}{ Dependent variable } \\
\hline & & CSR strategy & $\begin{array}{c}\text { Environmental } \\
\text { performance }\end{array}$ & $\begin{array}{l}\text { Board CSR } \\
\text { orientation }\end{array}$ \\
\hline $\begin{array}{l}\text { Board CSR orientation } \\
\text { (H1) }\end{array}$ & + & $\begin{array}{c}0.216 \\
(6.42)^{* * *}\end{array}$ & & \\
\hline CSR strategy (H2) & + & & $\begin{array}{c}0.539 \\
(31.45)^{* * *}\end{array}$ & \\
\hline $\begin{array}{l}\text { Environmental } \\
\text { performance (H3) }\end{array}$ & $+/-$ & & & $\begin{array}{c}0.152 \\
(3.60)^{* * *}\end{array}$ \\
\hline Firm size & + & $\begin{array}{c}0.382 \\
(15.38)^{* * *}\end{array}$ & $\begin{array}{c}0.251 \\
(13.31)^{* * *}\end{array}$ & $\begin{array}{c}0.278 \\
(7.07)^{* * *}\end{array}$ \\
\hline Slack & + & $\begin{array}{l}0.002 \\
(0.08)\end{array}$ & & \\
\hline Profitability & + & & $\begin{array}{l}-0.019 \\
(-1.23)\end{array}$ & \\
\hline Capital expenditure & + & & $\begin{array}{c}0.047 \\
(2.88)^{* *}\end{array}$ & \\
\hline Block shareholdings & - & & $\begin{array}{c}-0.094 \\
(-5.96)^{* * *}\end{array}$ & $\begin{array}{c}-0.462 \\
(-14.20) * * *\end{array}$ \\
\hline Board duality & - & & & $\begin{array}{l}-0.033 \\
(-1.05)\end{array}$ \\
\hline Intercept & & $\begin{array}{c}-1.571 \\
(-9.33)^{* * *}\end{array}$ & $\begin{array}{c}-0.965 \\
(-6.60)^{* * *}\end{array}$ & \\
\hline
\end{tabular}

Measurement model:

\begin{tabular}{c|c|c|c|c}
\hline \multirow{2}{*}{ Latent construct } & \multirow{2}{*}{$\begin{array}{c}\text { Predicted } \\
\text { sign }\end{array}$} & $\begin{array}{c}\text { Board } \\
\text { independence }\end{array}$ & Board diversity & $\begin{array}{c}\text { Audit committee } \\
\text { expertise }\end{array}$ \\
\cline { 3 - 5 } & + & 0.552 & 0.369 & 0.442 \\
Board CSR orientation & $(17.26)^{* * *}$ & $(13.86)^{* * *}$ & $(15.53)^{* * *}$ \\
\hline Intercept & & 2.439 & 0.066 & 0.441 \\
& & $(11.96)^{* * *}$ & $(0.49)$ & $(3.27)^{* *}$ \\
\hline
\end{tabular}

Model summary:

\begin{tabular}{l|l}
\hline Observations & 2028 \\
\hline Overall R-squared & 0.549 \\
\hline Root Mean Squared Error of Approximation (RMSEA) & 0.068 \\
\hline Comparative Fit Index (CFI) & 0.919 \\
\hline Normed Fit Index (NFI) & 0.912 \\
\hline
\end{tabular}

Note: Standardized coefficients are reported. Z-statistics are in parentheses. All variables are as defined in the "Variables and Models" section.

$\dagger$ p.10

* p .05

** p .01

*** p .001. 
TABLE 5

Results of Structural Equation Model with Social Performance

\begin{tabular}{|c|c|c|c|c|}
\hline \multicolumn{5}{|c|}{ Structural model: } \\
\hline \multirow[b]{2}{*}{ Independent variable } & \multirow{2}{*}{$\begin{array}{l}\text { Predicted } \\
\text { sign }\end{array}$} & \multicolumn{3}{|c|}{ Dependent variable } \\
\hline & & CSR strategy & $\begin{array}{c}\text { Social } \\
\text { performance }\end{array}$ & $\begin{array}{l}\text { Board CSR } \\
\text { orientation }\end{array}$ \\
\hline $\begin{array}{l}\text { Board CSR orientation } \\
(\mathrm{H} 1)\end{array}$ & + & $\begin{array}{c}0.200 \\
(5.90)^{* * *}\end{array}$ & & \\
\hline CSR strategy (H2) & + & & $\begin{array}{c}0.494 \\
(28.29)^{* * *}\end{array}$ & \\
\hline Social performance (H3) & $+/-$ & & & $\begin{array}{c}0.215 \\
(4.90)^{* * *}\end{array}$ \\
\hline Firm size & + & $\begin{array}{c}0.388 \\
(15.63)^{* * *} \\
\end{array}$ & $\begin{array}{c}0.294 \\
(15.77)^{* * *} \\
\end{array}$ & $\begin{array}{c}0.245 \\
(6.14)^{* * *} \\
\end{array}$ \\
\hline Slack & + & $\begin{array}{l}-0.000 \\
(-0.01)\end{array}$ & & \\
\hline Profitability & + & & $\begin{array}{l}-0.014 \\
(-0.88)\end{array}$ & \\
\hline Capital expenditure & + & & $\begin{array}{l}-0.024 \\
(-1.49)\end{array}$ & \\
\hline Block shareholdings & - & & $\begin{array}{c}-0.090 \\
(-5.75)^{* * *} \\
\end{array}$ & $\begin{array}{c}-0.454 \\
(-13.81) \\
\end{array}$ \\
\hline Board duality & - & & & $\begin{array}{l}-0.029 \\
(-0.93) \\
\end{array}$ \\
\hline Intercept & & $\begin{array}{c}-1.569 \\
(-9.25)^{* * *}\end{array}$ & $\begin{array}{c}-0.952 \\
(-6.57)^{* * *}\end{array}$ & \\
\hline
\end{tabular}

Measurement model:

\begin{tabular}{l|c|c|c|c}
\hline \multirow{2}{*}{ Latent construct } & \multirow{2}{*}{$\begin{array}{c}\text { Predicted } \\
\text { sign }\end{array}$} & $\begin{array}{c}\text { Board } \\
\text { independence }\end{array}$ & Board diversity & $\begin{array}{c}\text { Audit committee } \\
\text { expertise }\end{array}$ \\
\cline { 3 - 5 } Board CSR orientation & + & $\begin{array}{c}0.554 \\
(17.54)^{* * *}\end{array}$ & $\begin{array}{c}0.376 \\
(14.32)^{* * *}\end{array}$ & $\begin{array}{c}0.429 \\
(15.02)^{* * *}\end{array}$ \\
\hline Intercept & & 2.477 & 0.077 & 0.499 \\
& & $(12.37)^{* * *}$ & $(0.58)$ & $(3.79)^{* * *}$ \\
\hline
\end{tabular}

Model summary:

\begin{tabular}{l|l}
\hline Observations & 2028 \\
\hline Overall R-squared & 0.567 \\
\hline Root Mean Squared Error of Approximation (RMSEA) & 0.065 \\
\hline Comparative Fit Index (CFI) & 0.928 \\
\hline Normed Fit Index (NFI) & 0.920 \\
\hline
\end{tabular}

Note: Standardized coefficients are reported. Z-statistics are in parentheses. All variables are as defined in the "Variables and Models" section.

$\dagger \mathrm{p} .10$

$*$ p .05

** p .01

*** p .001. 
FIGURE 1

Existing Literature (Two Streams)

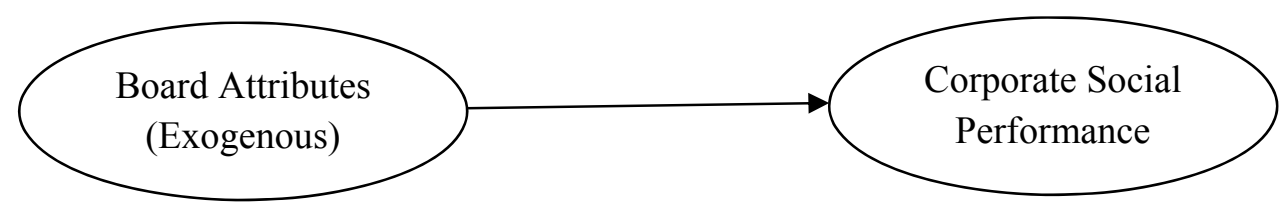

Stream 1: Resource dependence theory (RDT)

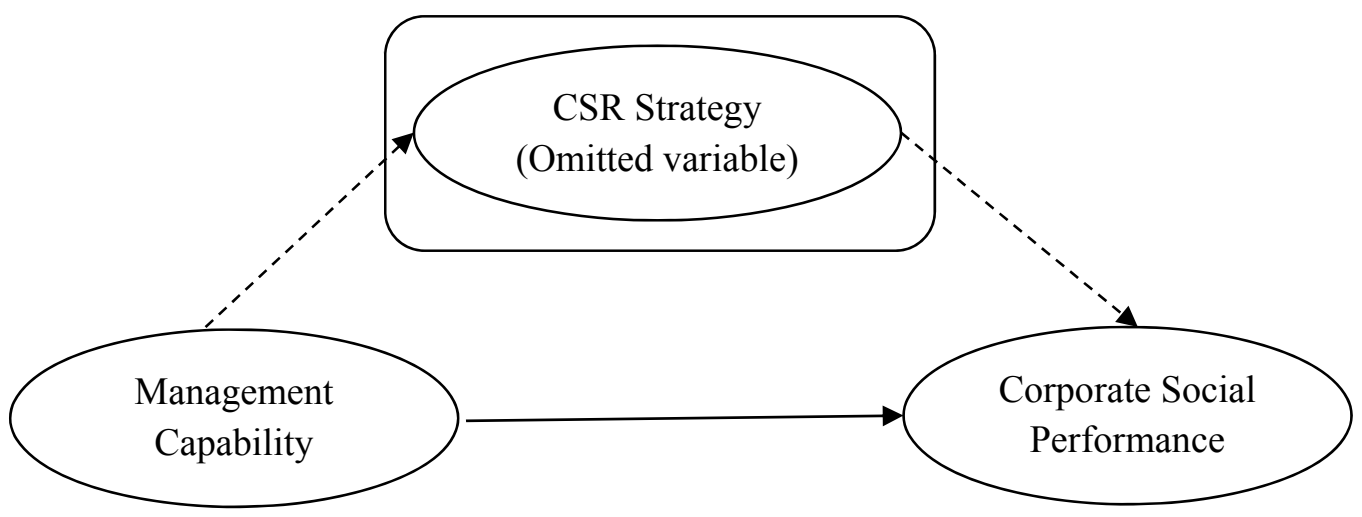

Stream 2: Resource-based view of the firm (RBV) 


\section{FIGURE 2}

\section{Theoretical Model}

Measurement model:

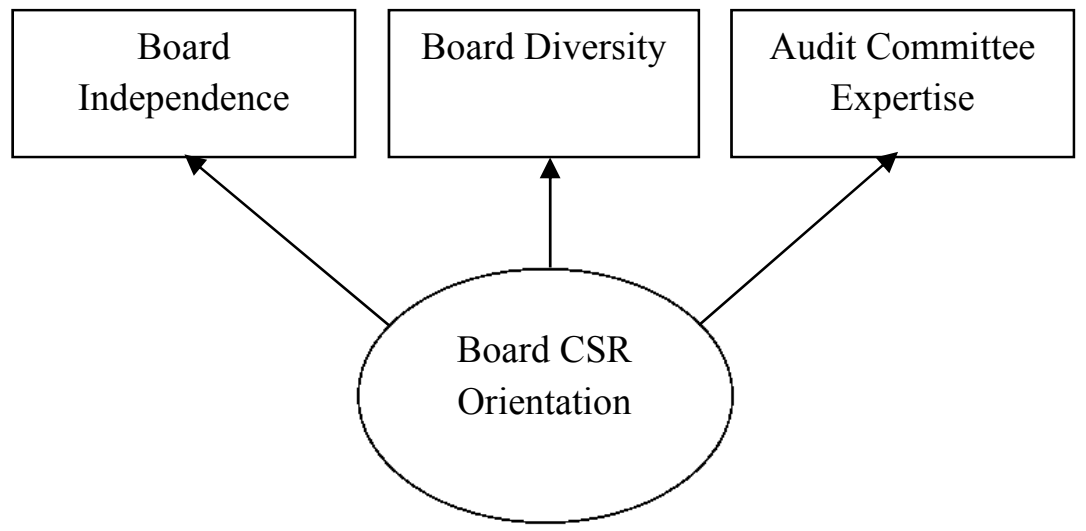

Structural model (core model excluding exogenous variables used in the system):

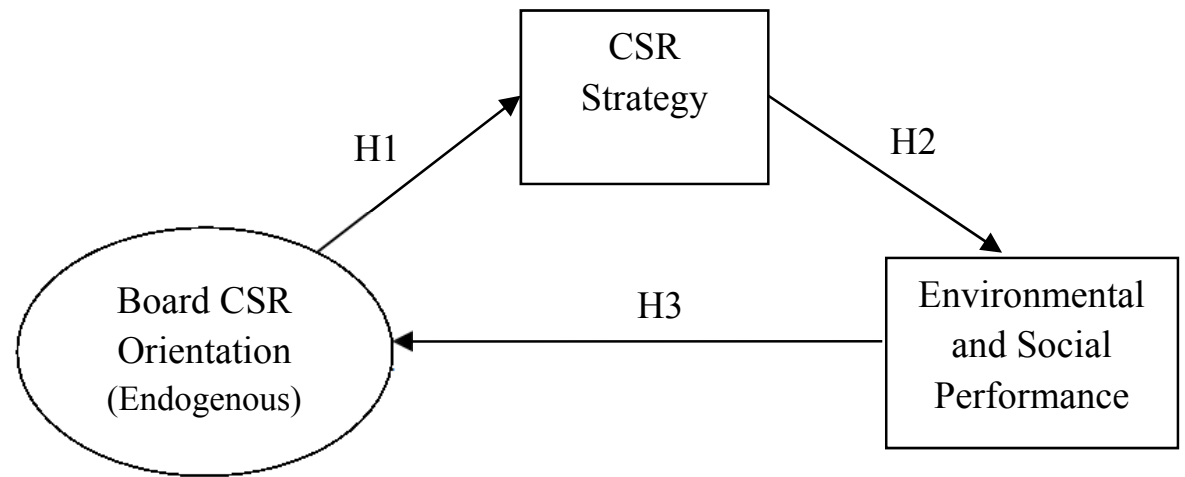

Adapted from Hermalin and Weisbach (2003) 


\section{Abbreviations}

CEO Chief executive officer

CERES California Environmental Resources Evaluation System

CFI Comparative fit index

CG Corporate governance

CSP Corporate social performance

CSR Corporate social responsibility

DJ Dow Jones

ESG Environmental, social and governance

FRC Financial Reporting Council

FTSE $\quad$ Financial Times Stock Exchange Group

GRI Global Reporting Initiative

ICB Industry Classification Benchmark

KLD Kinder Lydenberg Domini

KPI Key performance indicators

NFI Normed fit index

RBV Resource-based view (of the firm)

RDT Resource dependence theory

RMSEA Root mean squared error of approximation

ROE Return on equity

SEM Structural equation modeling

UK United Kingdom

US United States 